\title{
Perilaku Merokok Siswa SMP di Kecamatan Panongan Kabupaten Tangerang Tahun 2015
}

\section{Smoking Behavior at Junior High School's Students in Panongan Subdistrict Tangerang District 2015}

\author{
Rina Khairunnisa Fadii ${ }^{(1)}$, Anhari Achadi(2) \\ ${ }^{(1)}$ Fakultas Ilmu-Ilmu Kesehatan Universitas Muhammadiyah Prof Dr. Hamka Jakarta, Indonesia \\ ${ }^{(2)}$ Fakultas Kesehatan Masyarakat Universitas Indonesia, Indonesia
}

Korespondensi Penulis: Rina Khairunnisa Fadli, Program Studi Kesehatan Masyarakat, Fakultas Ilmu-Ilmu Kesehatan Universitas Muhammadiyah Prof.Dr. Hamka Jakarta

Email: rina_khairunnisa@uhamka.ac.id

\begin{abstract}
ABSTRAK
Perilaku merokok di kalangan siswa SMP terutama di Kecamatan Panongan sudah cukup memprihatinkan. Penelitian ini bertujuan untuk melihat faktor-faktor yang berhubungan dengan perilaku merokok siswa SMP di Kecamatan Panongan dilihat dari pendekatan dari Lawrence Green. Penelitian ini menggunakan desain Cross Sectional dengan didukung pendekatan kualitatif. Jumlah sampel sebanyak 230 siswa ditambah dengan 6 Informan untuk wawancara mendalam. Hasil penelitian menunjukkan bahwa perilaku merokok lebih banyak pada siswa laki-laki yang memiliki sikap negatif kemudian akses yang mudah terhadap rokok, memiliki keluarga dengan perilaku yang kurang baik dan teman yang kurang baik pula. Maka variabel yang berhubungan secara signifikan antara lain variabel umur ( $\mathrm{p}$ value $=0,044)$, jenis kelamin $(\mathrm{p}$ value $=0,000)$, sikap ( $\mathrm{p}$ value $=0,000)$, akses ( $\mathrm{p}$ value $=0,000)$, keluarga ( $\mathrm{p}$ value $=0,006)$ dan teman sebaya ( $\mathrm{p}$ value $=0,000)$ terhadap perilaku merokok siswa, sedangkan tingkat pengetahuan dan peraturan sekolah tidak memiliki hubungan yang signifikan dengan perilaku merokok. Akses menjadi faktor dominan yang mempengaruhi perilaku merokok siswa di SMP Kecamatan Panongan. Di sekolah belum ada peraturan khusus mengenai larangan merokok dan belum pernah ada sosialisasi peraturan dari kabupaten terkait larangan merokok sampai ke tingkat sekolah.
\end{abstract}

Kata Kunci: Rokok, Siswa, Iklan Rokok, Peraturan Sekolah

\begin{abstract}
Smoking behavior at Junior High School area especially at Panongan Subdistrict has been apprehensive about enough. The study head for analyze the correlation between smoking behavior with used Lawrence Green Theory. The study used Cross Sectional Design that be supported with qualitative approach. There were 230 respondents and 6 informan to indepth interview. The result showed that smoking behavior more on boys students that have negative attitude and simple access to the cigarette, they have bad family and bad friends too. There was a significant correlation are age $(p$ value $=0.044)$, sex $(p$ value $=0.000)$, attitude $(p$ value $=0.000)$, access $(p$ value $=0.000)$, family interaction $(p$ value $=0.006)$ and peer group $(p$ value $=0.000)$ to the smoking behavior. Meanwhile there wasn't correlation in knowledge and school's regulation. Access was the most important factor that influenced smoking behavior. There wasn't specific regulation about smoking prohibition at school and there wasn't socialization about regulation from Tangerang district to the junior high school at Panongan Subdistrict.
\end{abstract}

Keywords: Cigarettes, Students, Cigarette Advertisement, School's Regulation 


\section{PENDAHULUAN}

Indonesia merupakan negara nomor 3 (tiga) dengan jumlah perokok tertinggi di dunia setelah Cina dan India (Kemenkes, 2013). Proporsi penduduk umur $\geq 15$ tahun yang merokok dan mengunyah tembakau cenderung meningkat, berdasarkan Riskesdas 2007 sebesar 34,2 persen, Riskesdas 2010 sebesar 34,7 persen dan Riskesdas 2013 menjadi 36,3 pesen (Riskesdas 2013).

Berdasarkan hasil survei dari Global Youth Tobacco Survey (GYTS) pada tahun 2009 menunjukkan bahwa saat ini pelajar usia 13-15 adalah perokok aktif dengan prosentase sebesar $20,3 \%$. Perokok pemula remaja usia $10-14$ tahun naik 2 kali lipat dalam 10 tahun terakhir dari $9,5 \%$ pada tahun 2001 menjadi 17,5\% pada tahun 2010, sementara perokok pemula usia 1519 tahun menurun dari 58,9\% menjadi 43,3\%. Keadaan ini menunjukkan telah terjadi pergeseran perokok pemula ke kelompok usia yang lebih muda (Kemenkes, 2013).

Beberapa faktor yang mempengaruhi anak-anak usia muda menggunakan rokok yaitu: sosial dan lingkungan fisik, lingkungan sosial kecilnya, kognitif dan proses afektifnya, faktor biologi dan genetik, dan faktor lainnya seperti ekonomi yang rendah, akses, kemudahan serta harga dari rokok sendiri, pendidikan yang rendah dan keterpaparan terhadap iklan rokok, informasi dan lain - lain (CDC, 2013) dalam Pakpahan (2013). Penelitian di berbagai kota menjelaskan adanya hubungan antara pengetahuan dan sikap dengan perilaku merokok para siswa.

Provinsi Banten memiliki 8 kabupaten/kota dengan Kabupaten Tangerang sebagai wilayah dengan jumlah penduduk terbanyak. Kabupaten Tangerang memiliki kurang lebih sebanyak 29 kecamatan dengan wilayah kecamatan yang memiliki laju pertumbuhan penduduk tertinggi adalah pada wilayah Kecamatan Panongan.

Sebagaimana studi pendahuluan yang dilakukan oleh peneliti, diperoleh informasi bahwa fenomena perilaku merokok pada siswa SMP sudah dapat dikatakan memprihatinkan, guru lain menyebutkan persensentase siswa SMP yang merokok di sekolahnya kurang lebih sudah mencapai $20 \%$. Adapun sekolah lainnya menyatakan bahwa siswanya memang sudah ada yang memiliki kebiasaan merokok walaupun tidak di lingkungan sekolah. Berdasarkan hal tersebut, perlu dilakukan penelitian lebih lanjut untuk mengetahui faktor
- faktor yang berhubungan dengan perilaku merokok pada siswa SMP di Kecamatan Panongan sehingga dapat diperoleh bahan masukan informasi bagi sekolah-sekolah terkait dalam upaya mencegah para siswanya terus melakukan kebiasaan merokok.

\section{SUBYEK DAN METODE}

Penelitian ini dilakukan pada bulan Maret - April 2015 di sekolah negeri dan swasta dengan sekolah yang dipilih adalah SMPN 1 Panongan dan SMP Mandiri. Dua sekolah tersebut merupakan SMP dengan jumah siswa terbanyak di Kecamatan Panongan di antara beberepa sekolah yang ada di Kecamatan Panongan. Penelitian ini menggunakan metode penelitian kuantitatif dengan desain cross sectional. Instrumen yang digunakan adalah kuesioner untuk siswa, serta pedoman wawancara mendalam dan lembar checklist untuk para guru dan kepala sekolah.

Cara pengambilan sampel yang digunakan yaitu proportional stratified random sampling. Perhitungan sampel menggunakan estimasi beda dua proporsi, dengan besar P1 dan P2 didapat dari hasil penelitian sebelumnya yang terkait dengan faktor yang mempengaruhi perilaku merokok. Angka yang didapatkan untuk sampel minimal yaitu 102 dari penelitian sebelumnya kemudian dikalikan dua menjadi 204, untuk mengantisipasi sampel ditambahkan $10 \%$ dari jumlah minimal menjadi 224 kemudian penulis bulatkan menjadi 230 .

Pengumpulan data dilakukan kepada sampel penelitian yang berjumlah sebanyak 230 orang ini berasal dari dua SMP di kecamatan Panongan. Penelitian ini juga melibatkan 6 orang informan untuk dilakukan wawancara mendalam terkait perilaku merokok. Konsep penelitian ini mengacu pada model Lawrence Green yang melihat hubungan antara variabel independen (faktor predisposisi, faktor pemungkin dan faktor penguat) dengan variabel dependen yaitu perilaku merokok siswa SMP di Kecamatan Panongan.

Pengambilan data primer dilakukan dengan pengisisan kuesioner oleh para siswa serta proses wawancara mendalam terhadap beberapa guru dan kepala sekolah terkait perilaku merokok pada siswanya. Selain itu peneliti juga melakukan observasi di lingkungan sekolah. Analisis statistik yang dilakukan secara univariat, bivariat dan multivariat. Analisis multivariat pada penelitian kali ini menggunakan uji regresi logistik 
berganda yang merupakan pendekatan yang digunakan untuk menganalisis hubungan satu atau beberapa variabel independen dengan variabel dependen.

\section{HASIL}

Hasil penelitian faktor-faktor yang berhubungan dengan perilaku merokok siswa SMP di Kecamatan Panongan dapat dilihat sebagai berikut:

Tabel 1. Distribusi Perilaku Merokok Responden

\begin{tabular}{lcc}
\hline \multicolumn{1}{c}{ Perilaku Merokok } & Jumlah & Persentase (\%) \\
\hline Status Merokok Dulu (N=230) & & \\
$\quad$ Tidak Merokok & 127 & 55,2 \\
Merokok & 100 & 43,5 \\
Missing & 3 & 1,3 \\
Jumlah & $\mathbf{2 3 0}$ & $\mathbf{1 0 0}$ \\
Status Merokok Sekarang dari yang & & \\
Dulu Merokok(N=100) & & 64 \\
$\quad$ Tidak Merokok & 64 & 36 \\
$\quad$ Merokok & 36 & $\mathbf{1 0 0}$ \\
Jumlah & $\mathbf{1 0 0}$ & \\
Jumlah Rokok Per Hari pada siswa & & 80,5 \\
yang sekarang merokok (N=36) & 29 & 16,7 \\
$\quad$ 5 Batang & 6 & 2,8 \\
5- 10 Batang & 1 & $\mathbf{1 0 0}$ \\
>10 Batang & $\mathbf{1 0 0}$ & \\
Jumlah & &
\end{tabular}

Distribusi pada responden antara yang merokok dan tidak merokok masing - masing adalah $43,5 \%$ dan $55,2 \%$. Tabel 5.1 menunjukkan gambaran distribusi responden antara yang merokok dan tidak merokok. Dari 100 siswa yang dulunya perokok tinggal tersisa $36 \%$ yang masih merokok saat ini dengan jumlah rokok per harinya tertinggi di bawah 5 batang/hari $80,5 \%$.

Selanjutnya peneliti melakukan wawancara dengan beberapa responden dari kedua sekolah tersebut, terdapat pernyataan yang mengindikasi bahwa memang perilaku merokok pada siswa SMP di sekolah mereka sudah ada bahkan ada yang menyatakan prosentasenya sudah mencapai $20 \%$. Berikut adalah cuplikan pernyataan dari informan.

"sudah, merokok sudah banyak, wong itu baunya anak-anak yang terlambat, terutama yang bandel-bandel, tapi emang prosentase nya nggak banyak 20-25\% lah ya istilahnya kalo di prosentasekan, karena katakanlah lakilaki yang di kelas itu misalnya 20, sekitar 5 udah ngerokok. (IF1)"

Informan di atas menyatakan bahwa memang yang merokok adalah siswa yang memiliki kepribadian yang kurang baik di sekolah. Di samping itu dari sekolah yang berbeda seorang guru menyatakan bahwa memang ada siswanya yang merokok terkadang di sekolah saat ada jam kosong, namun lebih seringnya memang di luar sekolah. Berikut cuplikan pernyataannya.

"rata-rata di luar sekolah, kadang memang ada anak yang tiba tiba ada jam kosong kemudian juga ada kelas yang kosong, suka juga nyolong-nyolong gitu, memang pernah ketahuan." (IF4) 


\section{Hubungan Faktor Predisposisi dengan Perilaku Merokok Siswa}

Tabel 2. Hubungan antara faktor predisposisi dengan perilaku merokok siswa

\begin{tabular}{|c|c|c|c|c|c|c|c|c|}
\hline \multirow{3}{*}{$\begin{array}{c}\text { Faktor } \\
\text { Predisposisi }\end{array}$} & \multicolumn{4}{|c|}{ Perilaku Merokok } & & & \multirow{3}{*}{ OR $(95 \% \mathrm{CI})$} & \multirow{3}{*}{ p value } \\
\hline & \multicolumn{2}{|c|}{$\begin{array}{c}\text { Tidak } \\
\text { Merokok }\end{array}$} & \multicolumn{2}{|c|}{ Merokok } & \multicolumn{2}{|c|}{ Total } & & \\
\hline & $\mathrm{n}$ & $\%$ & $\mathrm{n}$ & $\%$ & $\mathrm{n}$ & $\%$ & & \\
\hline \multicolumn{9}{|l|}{ Umur } \\
\hline$\leq 14$ tahun & 90 & 60,8 & 58 & 39,2 & 148 & 100 & 0,568 & \multirow{3}{*}{0,044} \\
\hline$>14$ tahun & 37 & 46,8 & 42 & 53,2 & 79 & 100 & $(0,327-0,986)$ & \\
\hline Jumlah & 127 & 55,9 & 100 & 44,1 & 227 & 100 & & \\
\hline \multicolumn{9}{|l|}{ Jenis Kelamin } \\
\hline Laki - laki & 34 & 26 & 97 & 74 & 131 & 100 & 0,008 & \multirow{3}{*}{0,000} \\
\hline Perempuan & 93 & 97,9 & 2 & 2,1 & 95 & 100 & $(0,002-0,032)$ & \\
\hline Jumlah & 127 & 56,2 & 99 & 43,8 & 226 & 100 & & \\
\hline \multicolumn{9}{|l|}{ Pengetahuan } \\
\hline Baik & 62 & 51,2 & 59 & 48,8 & 121 & 100 & 0,663 & \multirow{3}{*}{0,126} \\
\hline Kurang baik & 65 & 61,3 & 41 & 38,7 & 106 & 100 & $(0,391-1,125)$ & \\
\hline Jumlah & 127 & 55,9 & 100 & 44,1 & 227 & 100 & & \\
\hline \multicolumn{9}{|l|}{ Sikap } \\
\hline Positif & 81 & 73,0 & 30 & 27,0 & 95 & 100 & 4,436 & \multirow{3}{*}{0,000} \\
\hline Negatif & 42 & 37,8 & 69 & 62,2 & 127 & 100 & $(2,514-7,828)$ & \\
\hline Jumlah & 123 & 55,4 & 99 & 44,6 & 222 & 100 & & \\
\hline
\end{tabular}

Pada tabel di atas menggambarkan hubungan antara faktor predisposisi (umur, jenis kelamin, pengetahuan dan sikap) dengan perilaku merokok. Hasil analisis menunjukkan bahwa pada siswa yang berumur kurang dari sama dengan 14 tahun yang sudah merokok sebesar 39,2\%, sementara pada siswa yang berumur lebih dari 14 tahun yang sudah merokok sebesar 53,2\%. Hasil uji statistik menunjukkan nilai $\mathrm{p}=0,044$, berarti ada perbedaan proporsi merokok antara responden yang berumur kurang dari sama dengan 14 tahun dan lebih dari 14 tahun.

Hasil analisis hubungan antara jenis kelamin dan perilaku merokok menunjukkan bahwa dari semua laki - laki, proporsi kejadian merokok sebesar $74 \%$, dan pada perempuan sebesar 2,1\%. Nilai $\mathrm{p}=0,000$ menunjukkan adanya perbedaan proporsi antara perempuan dan laki - laki dalam kaitannya dengan perilaku merokok. Sedangkan, pada analisis hubungan antara pengetahuan dan perilaku merokok menunjukkan bahwa responden yang berpengetahuan baik dan merokok sebesar $48,8 \%$, sementara yang berpengetahuan kurang baik dan merokok sebesar $38,7 \%$. Nilai p value $=0,126$ menunjukkan tidak ada perbedaan proporsi antara responden yang berpengetahuan baik dan kurang baik dalam kaitannya dengan perilaku merokok. Adapun analisis terhadap variabel sikap, ternyata siswa yang memiliki sikap positif dan merokok sebesar $27,0 \%$, sedangkan yang memiliki sikap negatif dan merokok sebesar $62,2 \%$. nilai $\mathrm{p}=$ 0,000 menunjukkan adanya perbedaan proporsi antara siswa yang memiliki sikap positif dan negative dimana siswa yang memiliki sikap yang negatif memiliki peluang 4,4 kali lebih besar untuk merokok dibandingkan dengan siswa yang memiliki sikap positif. 


\section{Hubungan antara faktor pemungkin dengan perilaku merokok siswa}

Tabel 3. Hubungan antara faktor pemungkin dengan perilaku merokok siswa

\begin{tabular}{|c|c|c|c|c|c|c|c|c|}
\hline \multirow{3}{*}{$\begin{array}{c}\text { Faktor } \\
\text { Pemungkin }\end{array}$} & \multicolumn{4}{|c|}{ Perilaku Merokok } & \multicolumn{2}{|c|}{ Total } & \multirow[t]{3}{*}{ OR $(95 \%$ CI $)$} & \multirow{3}{*}{$\begin{array}{l}\text { Nilai P } \\
\text { value }\end{array}$} \\
\hline & \multicolumn{2}{|c|}{ Tidak Merokok } & \multicolumn{2}{|c|}{ Merokok } & & & & \\
\hline & $\mathrm{n}$ & $\%$ & $\mathrm{n}$ & $\%$ & $\mathrm{n}$ & $\%$ & & \\
\hline Akses & & & & & & & 1,347 & 0,000 \\
\hline Sulit & 90 & 74,4 & 31 & 25,6 & 121 & 100 & $(1,224-1,482)$ & \\
\hline Mudah & 37 & 34,9 & 69 & 65,1 & 106 & 100 & & \\
\hline Jumlah & 127 & 55,9 & 100 & 44,1 & 227 & 100 & & \\
\hline
\end{tabular}

Hasil analisis bivariat terhadap faktor pemungkin, yaitu akses terhadap rokok adalah pada akses yang sulit, jumlah responden yang merokok sebesar 25,6\%, sedangakan pada akses yang mudah, jumlah responden yang merokok sebesar $65,1 \%$ dengan nilai $\mathrm{p}$ value $=$ 0,000 yang artinya ada perbedaan proporsi antara responden yang memiliki akses sulit dan responden yang memiliki akses mudah terhadap rokok. Dimana siswa yang memiliki akses mudah terhadap merokok memiliki peluang 1,3 kali lebih besar untuk merokok dibandingkan dengan siswa yang aksesnya sulit terhadap rokok.

Dari hasil wawancara, memang diketahui bahwa sekolah melarang para pedagang di kantin untuk menjual rokok sehingga para siswa tidak dapat membeli rokok di lingkungan sekolah, berikut adalah cuplikan pernyataannya.

"yang penting itu di kantin itu yang utama, tidak diperbolehkan jual rokok, nah itu yang utama itu. " (IF1)

Pedagang di kantin memang dilarang menjual rokok, namun ada beberapa dari pedagang kantin tersebut yang merokok di area kantin, berikut cuplikan pernyataannya.

"orang-orang di kantin? Kalo di kantin mah emang ngga ada yang ngerokok kan rata-rata yang dagang mah ibu-ibu, tapi ada juga sih beberapa orang, ada bapak-bapaknya yang ngerokok”. (IF3)
Namun memang tidak hanya dari pedagang di kantin, karena tidak menutup kemungkinan ada siswa yang membawa dari luar, peristiwa ini pernah terjadi di salah satu sekolah saat di inspeksi mendadak di kelas terdapat siswa yang membawa rokok di dalam tas nya, begitu ditanyakan ternyata rokok tersebut dibelikan oleh orang tuanya.

“rokok darima na ini? Dari bapak Bu." (IF1)

"orang tuanya kalau misalkan anaknya merokok nah itu dibiarkan malah terkadang dibelikan gitu berapa bungkus misalkan jadi bukan malah dilarang. (IF5)"

Selain dari dukungan orang tua, para siswa di daerah Kecamatan Panongan juga seringkali terpapar dengan acara konser musik yang diisi oleh grup musik yang sedang diidolakan para remaja saat ini, namun memang acara musik tersebut disponsori sepenuhnya oleh perusahaan rokok. Hal ini di duga berpengaruh pada para siswa yang ikut menonton konser musik tersebut untuk mudah terpapar dengan iklan rokok melalui acara konser musik tersebut, berikut cuplikan hasil wawancaranya.

"bisa karena iklan, bisa karena pergaulan, bisa karena apa namanya iklan rokok itu pake pertunjukan musik, yang jadi pengunjungnya kan itu kebanyakan anak-anak muda." (IF4) 


\section{Hubungan antara faktor penguat dengan perilaku merokok}

Tabel 4. Hubungan Antara Faktor Penguat dengan Perilaku Merokok Siswa

\begin{tabular}{|c|c|c|c|c|c|c|c|c|}
\hline \multirow{3}{*}{ Faktor Penguat } & \multicolumn{4}{|c|}{ Perilaku Merokok } & \multirow{2}{*}{\multicolumn{2}{|c|}{ Total }} & \multirow{3}{*}{ OR $(95 \% \mathrm{CI})$} & \multirow{3}{*}{ p value } \\
\hline & \multicolumn{2}{|c|}{ Tidak Merokok } & \multicolumn{2}{|c|}{ Merokok } & & & & \\
\hline & $\mathrm{n}$ & $\%$ & $\mathrm{n}$ & $\%$ & $\mathrm{n}$ & $\%$ & & \\
\hline \multicolumn{9}{|l|}{ Keluarga } \\
\hline Tidak Baik & 54 & 47,0 & 61 & 53,0 & 103 & 100 & \multirow{3}{*}{$\begin{array}{c}2,114 \\
(1,240-3,607)\end{array}$} & \multirow{3}{*}{0,006} \\
\hline Baik & 73 & 65,2 & 39 & 34,8 & 124 & 100 & & \\
\hline Jumlah & 127 & 55,9 & 100 & 44,1 & 227 & 100 & & \\
\hline \multicolumn{7}{|l|}{ Teman Sebaya } & \multirow{4}{*}{$\begin{array}{c}1,559 \\
(1,360-1,786)\end{array}$} & \multirow{4}{*}{0,000} \\
\hline Tidak Baik & 18 & 24 & 57 & 76 & 75 & 100 & & \\
\hline Baik & 108 & 71,5 & 43 & 28,5 & 151 & 100 & & \\
\hline Jumlah & 126 & 55,8 & 100 & 44,2 & 226 & 100 & & \\
\hline \multicolumn{9}{|c|}{ Peraturan Sekolah } \\
\hline Tidak ada & 72 & 59 & 50 & 41 & 122 & 100 & 1,309 & \multirow{3}{*}{0,315} \\
\hline Ada & 55 & 52,4 & 50 & 47,6 & 105 & 100 & $(0,773-2,216)$ & \\
\hline Jumlah & 127 & 55,9 & 100 & 44,1 & 227 & 100 & & \\
\hline
\end{tabular}

Hasil analisis variabel pengaruh keluarga terhadap perilaku merokok siswa pada tabel di atas menunjukkan bahwa keluarga yang memiliki perilaku merokok yang tidak baik dan siswa tersebut merokok sebesar 53\%, sedangkan dari keluarga yang perilaku merokoknya baik, yang merokok sebesar $34,8 \%$ dengan nilai $\mathrm{p}$ value $=0,006$ yang menunjukkan bahwa ada perbedaan proporsi antara perilaku merokok keluarga yang baik dan tidak baik terhadap perilaku merokok siswanya. Dimana siswa yang perilaku merokok keluarganya tidak baik memiliki peluang 2,1 kali lebih besar untuk merokok dibandingkan siswa yang perilaku merokok keluarganya baik.

Menurut penuturan seorang guru, dikatakan bahwa rata-rata orang tua siswa SMP di sekolahnya memang merupakan perokok, jumlah orang tua yang merokok lebih besar dibandingkan dengan yang bukan perokok.

"hampir rata-rata orang tua siswa itu merokok, mungkin tidak ada sampai $10 \%$ wali murid yang tidak merokok." (IF3)

Hasil analisis terhadap pengaruh teman sebaya menunjukkan bahwa teman sebaya yang memiliki perilaku merokok yang tidak baik dan respondennya merokok sebesar $76 \%$. Sementara dari teman sebaya yang perilaku merokoknya baik dan merokok sebesar $28,5 \%$. Nilai $\mathrm{p}=0,000$ menunjukkan adanya perbedaan proporsi antara teman sebaya yang memiliki perilaku merokok yang baik dan buruk dalam mempengaruhi perilaku merokok siswa. OR =
1,6 menunjukkan bahwa siswa yang memiliki teman sebaya yang tidak baik memiliki peluang 1,6 kali lebih besar untuk merokok dibandingkan siswa yang teman sebayanya baik.

Pada variabel peraturan sekolah, sekolah yang memiliki peraturan sekolah dan siswanya merokok sebesar 47,6\%, sementara yang tidak memiliki peraturan sekolah dan siswanya merokok sebesar 41\%. $\mathrm{p}$ value $=0,315$ menunjukkan tidak adanya perbedaan proporsi antara sekolah yang memiliki peraturan merokok dan tidak merokok dalam mempengaruhi perilaku merokok siswanya. Terkait dengan peraturan sekolah para guru dan kepala sekolah memberikan jawaban yang serempak bahwa memang di sekolah mereka untuk larangan merokok hanya dituangkan berupa tata tertib, belum ada peraturan yang khusus mengatur mengenai larangan merokok pada siswa. Berikut beberapa cuplikan pernyataannya:

“secara umum di tata tertib.” (IF2)

"masih berupa larangan aja. Belum ada yang spesifik.” (IF5)

"sampai sekarang ini nggak ada, hanya di tata tertib, karena masih di level SMP mah masih belum urgent lah ya." (IF6)

Tata tertib yang ada pada kedua sekolah tersebut telah dibuat sejak lama bahkan sejak awal berdirinya sekolah. Dalam pelaksanaannya jika ditemukan kasus siswa 
yang merokok maka siswa tersebut akan dikenakan sanksi. Sanksi yang diberikan pun beragam, mulai dari teguran hingga pemanggilan orang tua, menulis surat pernyataan bahkan ada yang sampai dihukum berdiri di lapangan dengan dipakaikan tulisantulisan.

“iya ... sanksinya berupa teguran, kan ada tingkatannya, mulai dari teguran sampai pemanggilan orang tua." (IF2)

"kalau masih sekali dua kali mah ditegur aja, kalau udah tiga kali baru dihukum, di tengah lapangan." (IF4)

"mereka buat pernyataan saja, mereka buat pernyataan bahwa tidak akan mengulang lagi, tidak akan berbuat lagi di sekolah." (IF5)

"kalo ketahuan di kantin kan, digiring sama OSIS atau sama piket, di bawa ke tengah lapangan, tulisin disini (menunjuk dada) pake kertas "tidak akan merokok lagi" pokoknya dibikin dihukum sejera mungkin." (IF1)

Pihak yang bertanggungjawab untuk menangani siswa tersebut adalah guru BP, bagian kesiswaan, wali kelas, guru piket bahkan sampai kepala sekolah juga bertanggungjawab menangani apabila ditemukan siswa yang merokok di sekolah.

"yang paling bertanggung jawab itu kan bagian kesiswaan, itu bagian kesiswaan bersamasama dengan walikelas dan juga dengan BP. " (IF5)

"eh yang paling jelas mah harusnya wali kelas dulu, sebelum masuk ke BP wali kelas dulu, kepala sekolah mah udah paling akhir." (IF6)

Untuk mengetahui hubungan lebih dari satu variabel independen dengan dependen maka perlu dilakukan analisis multivariat. Analisis multivariat pada penelitian kali ini menggunakan uji regresi logistik berganda yang merupakan pendekatan yang digunakan untuk menganalisis hubungan satu atau beberapa variabel independen dengan variabel dependen. Penelitian ini menggunakan model prediksi dimana semua variabel prediktor sekaligus secara bersama - sama kedalam pengujian statistik. Hasil analisis menunjukkan bahwa variabel - variabel yang masuk ke dalam pemodelan multivariat adalah variabel umur, jenis kelamin, pengetahuan, sikap, akses, keluarga dan teman sebaya.

Tabel 5. Tahap 1 Pemodelan Multivariat

\begin{tabular}{lrrr}
\hline \multicolumn{1}{c}{ Variabel } & p value & OR & \multicolumn{1}{c}{$\mathbf{9 5 \%}$ CI } \\
\hline umur3(1) & & 0.486 & $0.157-1.500$ \\
umur3(2) & & 1.846 & $0.547-6.228$ \\
Jenis Kelamin & .000 & 0.006 & $0.000-0.034$ \\
Pengetahuan & .548 & 0.744 & $0.284-1.949$ \\
Sikap & .043 & 2.676 & $1.029-6.955$ \\
Akses & .000 & 7.590 & $2.697-21.358$ \\
Keluarga & .082 & 2.357 & $0.896-6.203$ \\
Teman & .034 & 0.335 & $0.122-0.919$ \\
\hline
\end{tabular}

Tabel 6. Hasil Akhir Pemodelan Multivariat

\begin{tabular}{lrrc}
\hline \multicolumn{1}{r}{ Variabel } & p value & OR & 95\% CI \\
\hline Umur3 & .078 & & \\
Umur3(1) & .198 & .478 & $.155-1.472$ \\
Umur3(2) & .319 & 1.851 & $.552-6.213$ \\
Jenis Kelamin & .000 & .006 & $.001-.032$ \\
Sikap & .034 & 2.774 & $1.078-7.141$ \\
Akses & .000 & 7.329 & $2.647-20.291$ \\
Keluarga & .078 & 2.384 & $.907-6.267$ \\
Teman & .038 & .348 & $.128-.942$ \\
\hline
\end{tabular}


Berdasarkan hasil akhir pemodelan multivariat dapat diketahui bahwa variabel yang paling berpengaruh terhadap perilaku merokok siswa yaitu variabel akses terhadap rokok. Variabel keluarga dan umur sebagai variabel pengontrol.

\section{DISKUSI}

Perilaku merokok yang cukup banyak ini juga sudah diketahui oleh para guru dan kepala sekolah pada sekolah terkait, walaupun memang siswa tersebut tidak merokok di dalam lingkungan sekolah kecuali secara sembunyisembunyi dan tidak terlihat oleh guru. Sebagian besar siswa laki-laki pada umumnya sudah merokok di usia SMP dengan beberapa alasan diantaranya ada yang hanya coba-coba ataupun agar terlihat keren di antara teman-teman lainnya. Perilaku merokok pada siswa ini dapat terjadi kemungkinan karena masih adanya contoh negatif perilaku dari warga sekolah yang masih merokok di lingkungan sekolah diantaranya di kantin, di ruang guru serta di parkiran sekolah.

Namun memang dari 100 siswa tersebut yang sampai saat pengambilan data dilaksanakan hanya sebanyak 36 siswa yang masih merokok, 64 siswa lainnya berhenti merokok dengan alasan terbanyak yaitu mereka menyadari bahwa merokok tidak baik untuk kesehatan, ada pula yang memberikan alasan bahwa siswa tersebut sudah bosan merokok. Melihat jumlah siswa yang memilih berhenti merokok dapat dikatakan bahwa kesadaran terhadap kesehatan para siswa tersebut sudah dapat dikatakan baik. Rata-rata siswa SMP dalam penelitian ini merokok kurang dari 5 batang setiap harinya seperti yang dikemukakan oleh Rofiq (2014) bahwa sebagian besar siswa $(69,5 \%)$ menghisap rokok kurang dari lima batang perhari sehingga dapat dikatakan bahwa siswa SMP di Kecamatan Panongan ini tergolong ke dalam perokok ringan.

Data dari Global Youth Tobacco Survey di Indonesia tahun 2009 menunjukkan bahwa pada usia 13-15 tahun sudah ada sekitar 20,3\% yang merokok. Pada usia serupa di SMP yang menjadi tempat penelitian persentasenya sudah mencapai 43,5\% maka dapat dikatakan bahwa siswa usia SMP di Kecamatan Panongan lebih tinggi angkanya dibandingkan dengan angka nasional yang hanya sebanyak 20,3\%. Pada uji analisis antara variabel umur dengan perilaku merokok menunjukkan adanya hubungan yang signifikan antara umur siswa dengan perilaku merokok. Penelitian yang dilakukan oleh Rofiq (2014) menyatakan bahwa siswa dengan usia > 14 tahun lebih berisiko untuk merokok dibandingkan dengan siswa dengan usia $\leq 14$ tahun. Selanjutnya penelitian yang dilakukan oleh Yunita (2008) juga menyatakan hal serupa bahwa siswa yang usianya 14-16 tahun memiliki peluang 3,8 kali lebih besar untuk merokok dibandingkan siswa yang usianya 1113 Tahun.

Persentase siswa laki - laki dan perempuan pada penelitian ini masing - masing adalah $57,4 \%$ dan $42,2 \%$. Hasil analisis hubungan antara jenis kelamin dan perilaku merokok menunjukkan bahwa dari semua laki - laki, proporsi kejadian merokok sebesar 74\%, dan pada perempuan sebesar 2,1\%. Data yang dipaparkan dalam Riskesdas 2013 menyatakan bahwa pada penduduk yang berusia $\geq 15$ tahun sebanyak $64,9 \%$ adalah perokok laki-laki, sedangkan sebelumnya dalam Global Adults Tobacco Survey Tahun 2011 memaparkan sebayak $67 \%$ adalah perokok laki-laki. Sedangkan untuk perokok perempuan pada Riskesdas 2013 disebutkan sebanyak 2,1 \% yang sebelumnya sebanyak $2,7 \%$ perokok perempuan berdasarkan GATS 2011. Perilaku merokok pada siswa perempuan di SMP Kecamatan Panongan adalah karena faktor coba-coba dan adanya masalah dalam keluarga. Keterangan ini didapat dari guru sekolah terkait. Namun perilaku merokoknya pun hanya sekali saja saat ini keduanya sudah tidak merokok lagi.

Pada variabel pengetahuan dalam penelitian menunjukkan bahwa tidak ada perbedaan proporsi antara responden yang berpengetahuan baik dan kurang baik dalam kaitannya dengan perilaku merokok. Rachmat, dkk (2010) juga menyatakan bahwa tidak ada hubungan antara pengetahuan dengan perilaku merokok pada remaja, siswa yang berpengetahuan rendah merokok sebanyak $16,7 \%$ dan siswa yang berpengetahuan tinggi merokok sebanyak $27 \%$ dengan nilai $\mathrm{p}$ value $=$ 0,056 . Dalam penelitian yang dilakukan oleh Yunita (2008) juga menyatakan tidak ada hubungan yang bermakna antara pengetahuan dengan perilaku merokok siswa. Tidak berkaitannya hubungan antara pengetahuan dengan perilaku merokok ini bertentangan dengan pernyataan Notoatmodjo (2010) dalam Raehana (2014) yang menyatakan bahwa pengetahuan merupakan domain yang sangat 
penting dalam terbentuknya tindakan seseorang (overt behavior). Namun melihat fakta masih terdapat beberapa siswa yang memiliki pengetahuan kurang maka perlu dilakukan sosialisasi secara berkelanjutan kepada siswa karena selama ini yang terjadi sosialisasi terkait rokok, bahaya merokok itu dilakukan hanya pada saat siswa tersebut menjalani masa orientasi yaitu saat awal masuk sebagai siswa SMP saja. Disamping itu perlu juga dipaparkan peraturan-peraturan terkait larangan merokok kepada para siswa dengan harapan siswa dapat mematuhi peraturan tersebut.

Hasil penelitian terhadap variabel sikap menunjukkan adanya perbedaan proporsi antara siswa yang memiliki sikap positif dan negatif terhadap perilaku merokok. Diketahui pula bahwa pada siswa yang memiliki sikap negatif berpeluang untuk merokok sebanyak 4,4 kali lebih besar dibandingkan dengan siswa yang memiliki sikap yang positif. Penelitian yang dikemukakan oleh Rofiq (2014) juga memaparkan hal serupa dimana terdapat hubungan yang signifikan antara sikap dengan perilaku merokok siswa ( $\mathrm{p}=0,0005)$, diketahui pula bahwa siswa dengan sikap negatif lebih berisiko merokok dibandingkan dengan siswa dengan sikap positif.

Variabel akses terhadap rokok ini merupakan gambaran dari faktor pendukung siswa dalam mendapatkan rokok, dan keterpaparan terhadap iklan rokok. Pada penelitian ini menunjukkan adanya perbedaan proporsi antara responden yang memiliki akses sulit dan responden yang memiliki akses mudah terhadap rokok. Siswa yang memiliki akses yang mudah memiliki peluang untuk merokok sebanyak 1,3 kali lebih besar dibandingkan dengan siswa yang memiliki akses yang sulit. Rachmat, dkk (2010) menyatakan bahwa iklan rokok sebagai media promosi rokok dan berbagai jenis sangat potensial membentuk sikap dan perilaku merokok remaja. Pengetahuan tentang rokok banyak didapatkan melalui iklan rokok, baik jenis rokok terbaru maupun bahaya dari rokok itu sendiri. Disebutkan ada 104 siswa yang menerima paparan iklan rokok dan merokok, kemudian ada 15 siswa yang tidak terkena paparan iklan namun tetap merokok. Raehana (2014) dalam penelitiannya juga menyatakan bahwa perilaku merokok pada responden yang sering tepapar dengan iklan rokok memiliki risiko 2,795 kali lebih besar dibandingkan dengan responden yang jarang terpapar iklan rokok.
Jika dilihat dari setiap pertanyaan pada variabel akses dapat diketahui bahwa memang pertanyaan terkait akses mencakup lingkungan sekitar siswa SMP tidak hanya di lingkungan sekolah, tetapi juga lingkungan sehari-harinya termasuk pada iklan rokok yang saat ini lebih banyak menampilkan hal-hal yang terlihat positif. Pada beberapa tayangan di televisi memang sudah ada iklan yang menayangkan dampak dari perilaku merokok terutama pada orang-orang di sekitar perokok tersebut, namun memang masih sedikit jumlah jam penayangannya dibandingkan dengan iklan rokok yang terlihat positif tadi. Sehingga kemungkinan yang terjadi adalah para siswa usia SMP lebih banyak terpapar dengan iklan rokok yang terlihat positif tersebut dan membentuk sikap dari para siswa untuk cenderung setuju terhadap perilaku merokok.

Berdasarkan penjelasan di atas yang diperkuat pula dengan uji statistik sampai dengan tingkat multivariat maka peneliti dapat menyimpulkan bahwa akses terhadap rokok merupakan faktor paling penting yang berhubungan dengan perilaku merokok siswa. Sebagai faktor terpenting yang berhubungan perilaku merokok pada siswa SMP, peneliti dapat memberikan masukan kepada pihak sekolah untuk segera membuat peraturan terkait larangan merokok di sekolah yang mencakup semua aspek. Peraturan ini diharapkan dapat mencegah terjadinya perilaku merokok pada pemula serta menghentikan kebiasaan merokok pada siswa yang memang sudah menjadi perokok, perlu diberlakukan sistem sanksi yang mendidik namun juga bersifat tegas yang dapat membuat jera siswa yang ketahuan merokok sehingga sadar dan tidak lagi merokok.

Pada variabel keluarga dalam penelitian ini diketahui bahwa terdapat hubungan yang bermakna antara variabel keluarga dengan perilaku merokok pada siswa, diketahui bahwa siswa yang memiliki keluarga dengan perilaku yang tidak baik memiliki peluang untuk merokok sebanyak 2,1 kali lebih besar dibandingkan dengan siswa yang perilaku keluarganya baik. Rofiq (2014) dalam penelitiannya memaparkan bahwa perilaku merokok keluarga memiliki hubungan yang bermakna dengan perilaku merokok pada siswa. Namun berbeda dengan penelitian Raehana (2014) yang justru memaparkan hal yang sebaliknya, yaitu tidak ada hungungan yang bermakna antara perilaku merokok keluarga dengan perilaku merokok siswa. 
Pernyataan dari para guru pun memperkuat bahwa rata-rata, bahkan ada guru di satu sekolah yang menyatakan bahwa hampir semua orang tua siswa di sekolah tersebut adalah seorang perokok. Jelas hal ini akan menjadi contoh yang kurang baik bagi sang anak. Pada dasarnya seorang anak itu melihat contoh terutama di lingkungan keluarga yang merupakan lingkungan dasar anak tersebut sebelum melangkah ke lingkungan yang lebih luas lagi. Leventhal, dkk (1988) dalam Smet (1994) menyatakan bahwa pengaruh keluarga merupakan faktor penentu kedua terpenting dalam mempengaruhi perilaku merokok pada anak. Menurut penelitian Rachmat dkk (2010), remaja yang tinggal serumah dengan orang tua yang merokok dan sering melihat mereka merokok akan meniru perilaku merokok orang tuanya tersebut karena orang tua menjadi model tingkah laku pada anak-anak, tidak terkecuali perilaku merokok.

Pada variabel teman sebaya dalam penelitian ini diketahui bahwa adanya perbedaan proporsi antara teman sebaya yang memiliki perilaku yang baik dan tidak baik dalam mempengaruhi perilaku merokok siswa. Hasil analisis ini sejalan dengan penelitian yang dilakukan oleh Raehana (2014) yang menemukan bahwa perilaku merokok pada teman sebaya memiliki hubungan yang bermakna dengan perilaku merokok siswa.

Pada variabel peraturan sekolah menunjukkan tidak adanya perbedaan proporsi antara sekolah yang memiliki peraturan merokok dan tidak merokok dalam mempengaruhi perilaku merokok siswanya. Dalam penelusuran peneliti dapat diketahui bahwa di SMP di Kecamatan Panongan memang belum ada peraturan khusus mengenai larangan merokok di sekolah. Kedua sekolah tempat peneliti mengambil data menjelaskan bahwa mereka hanya menerapkan tata tertib saja yang salah satu poinnya adalah dilarang merokok di lingkungan sekolah. Tata tertib yang diterapkan oleh kedua sekolah tersebut sudah sejak lama dibuat sehingga tidak mengacu kepada satu kebijakan dari bupati yang ditetapkan pada tahun 2012 lalu. Pada observasi lanjutan yang dilakukan peneliti belum menemukan tata tertib yang dimaksud terpasang di setiap kelas, tulisan-tulisan himbauan serta poster-poster mengenai larangan merokok sangat sedikit yang terpasang di sekolah. Bahkan dalam satu sekolah hanya ada satu papan kecil bertuliskan kawasan bebas asap rokok yang dipasang pada koridor di depan ruang guru. Padahal sebaiknya poster-poster atau tulisan himbauan dilarang merokok perlu dipasang dibanyak tempat dengan harapan orang yang akan merokok menyadari bahwa tempat-tempat yang termasuk ke dalam lingkungan sekolah merupakan area yang terlarang untuk merokok.

\section{KESIMPULAN}

Pada penelitian terkait dengan perilaku merokok siswa SMP di Kecamatan Panongan dapat disimpulkan bahwa Faktor yang mendorong siswa SMP di Kecamatan Panongan antara lain adalah faktor umur, jenis kelamin, sikap, akses, Keluarga dan Teman sebaya. Adapun akses terhadap rokok menjadi faktor yang dominan dalam mempengaruhi perilaku merokok siswa, karena terjadi dampak langsung dan tidak langsung dari variabel lainnya melalui variabel akses.

\section{DAFTAR PUSTAKA}

Kementrian Kesehatan Republik Indonesia. (2013). Peta Jalan Pengendalian Dampak Konsumsi Rokok Bagi Kesehatan. Jakarta, Lampiran Permenkes No.40 Tahun 2013. Kementrian Kesehatan RI.

Kementrian Kesehatan Republik Indonesia. (2014). Riskesdas 2007. Jakarta: Kementrian Kesehatan RI.

Kementrian Kesehatan Republik Indonesia. (2014). Riskesdas 2010. Jakarta: Kementrian Kesehatan RI.

Kementrian Kesehatan Republik Indonesia. (2014). Riskesdas 2013. Jakarta: Kementrian Kesehatan RI.

Kementrian Kesehatan Republik Indonesia. (2013). Peta Jalan Pengendalian Dampak Konsumsi Rokok Bagi Kesehatan. Jakarta, Lampiran Permenkes No.40 Tahun 2013. Kementrian Kesehatan RI.

Pakpahan, RP. (2013). The Efectiveness of Booklet for Improved Knowledge and Attitude about Cigarette and its Dangerous at SDN 01 Panjang Selatan, Panjang, Bandar Lampung. Jurnal. FK UNILA.

Rachmat, Muhammad dkk. (2010). Perilaku merokok Remaja Sekolah Menengah Pertama. Artikel Penelitian. FKM UNHAS.

Raehana. (2014). Faktor-faktor yang berhubungan dengan siswa/i merokok di SMP Negeri 36 Jakarta Timur Tahun 2014. Skripsi. FKMUI.

Rofiq, Ichsanu. (2014). Faktor- faktor yang berhubungan dengan perilaku merokok siswa SMP/MTs di Kecamatan Mojoagung Kabupaten Jombang Tahun 2014. Skripsi. FKMUI 
ARKESMAS, Volume 4, Nomor 2, Desember 2019 178

Yunita, Ratna. (2008). Hubungan Antara Perilaku Merokok Orang Tua Dengan Perilaku Merokok Siswa SMP Di Kota Bogor Tahun 2007. Tesis. FKMUI. 